\title{
Reliability and Validity of the Student Teacher Professional Identity Scale in Pre-Service Kindergarten Teachers
}

\author{
Li-Ying Zhang1, Xin-Qiang Wang2 ${ }^{*}$ \\ ${ }^{1}$ School of Education, Jiangxi Normal University, Nanchang, China \\ ${ }^{2}$ School of Psychology, Center for Mental Health Education and Research, Jiangxi Normal University, Nanchang, China \\ Email: *xinqiangw101@163.com
}

How to cite this paper: Zhang, L.-Y. and Wang, X.-Q. (2018) Reliability and Validity of the Student Teacher Professional Identity Scale in Pre-Service Kindergarten Teachers. Open Journal of Social Sciences, 6, 252-260. https://doi.org/10.4236/jss.2018.68021

Received: July 25, 2018

Accepted: August 24, 2018

Published: August 27, 2018

Copyright (c) 2018 by authors and Scientific Research Publishing Inc. This work is licensed under the Creative Commons Attribution International License (CC BY 4.0).

http://creativecommons.org/licenses/by/4.0/

\section{c) (i) Open Access}

\begin{abstract}
Objective: To revise and explore the application of the student teacher professional identity scale in pre-service kindergarten teachers (STPIS-PK). Methods: 450 preservice kindergarten teachers were surveyed by the student teacher professional identity scale. Results: 1 ) The EFA supported that teacher professional identity consisted of four subscales: professional values, professional willingness, professional efficiency and professional volition. Also the CFA confirmed the hypothesized four-factor model $\left(\mathrm{x}^{2}=133.277, \mathrm{x}^{2} / \mathrm{df}=\right.$ $2.777, \mathrm{CFI}=0.939$, TLI $=0.901, \mathrm{RMSEA}=0.047)$. The Criteria-related validity was remarkable; 2) The internal consistency of teacher professional identity scale was 0.801 and the four subscales were from 0.628 to 0.789 . For two weeks, the test-retest reliability was from 0.616 to 0.786 . Conclusion: In sum, this study generated evidence that the STPIS-PK developed in the study is a psychometrically sound and valid instruments to measure pre-service kindergarten teachers' professional identity.
\end{abstract}

\section{Keywords}

The Student Teacher Professional Identity Scale, Pre-Service Kindergarten Teachers, Reliability, Validity

\section{Introduction}

Preschool education is the education stage of life enlightenment, which is of great significance to children's physical and mental health, habit development and intellectual development, and conducive to laying a good foundation for future career success. Therefore, both the national program for medium-and 
long-term reform and development of education (2010-2020) and the state council's opinions on the current development of preschool education emphasize that pre-school education should be placed in a more important position [1]. Cultivating high-quality professional kindergarten teachers is the key to developing preschool education. Pre-service kindergarten teachers are the main source of preschool teachers in China. Their professional quality is directly related to the quality of future kindergarten teachers.

According to the current situation in China, there are many problems in the construction of preschool teachers, such as high mobility of preschool teachers, insufficient professional knowledge and poor overall quality, which are related to the lack of correct understanding and recognition of preschool education students on preschool teachers' career. FU supports this view, he believes that the quality of teachers is directly related to whether they are suitable and like to work as teachers [2]. The professional identity of pre-school education undergraduates refers to the internal psychological mechanism of individuals' reasonable understanding of preschool education, correct attitude and positive emotional experience [3]. Pre-school education majors' recognition of preschool education is the most lasting motive force for teachers' emotion and the basic psychological preparation for preschool education [4]. Therefore, the professional identity of pre-school students majoring in education will not only have an impact on their interest and attitude in school and their future career choice, but also affect the quality and stability of the contingent of preschool teachers in the future. Therefore, it is of great significance to study the professional identity of preschool education normal school students.

Teacher professional identity of normal school students refers to the comprehensive attitude of normal university students of accepting and identifying the teacher occupation they will be engaged in and the current status of normal university students, mainly including professional values, professional willingness, professional efficiency, professional volition and other aspects (Wang, Zeng, Zhang, \& Li, 2010) [5]. Wang et al. (2010) [5] designed the original scale by using the literature method and the expert consultation method, applied the measurement and modified the scale several times, and prepared the student teacher professional identity scales, which was used to evaluate the teacher professional identity of normal university students. As the scale has good reliability and validity, it is used as one of the common tools to evaluate the teacher professional identity of normal university students.

The research on the professional identity of preschool education normal school students has attracted wide attention in recent years. Wang and Xue (2011) [6] found that the pre-school education undergraduate students' professional identity status was generally good through questionnaire and individual interviews, but there were still some problems, and proposed to strengthen the professional identity of undergraduate students from social, school and personal aspects. Zhang et al. (2015) [7] conducted a questionnaire survey on 240 
pre-school students majoring in education in a university by using the adapted questionnaire on the identity of pre-school students majoring in education in their professional work. Yang and Zhao (2016) [8] independently compiled the professional identity survey questionnaire for preschool teachers of education major students in three-year colleges and universities, and combined with individual interviews, to further understand the underlying reasons behind the current status of professional identity of students' preschool teachers. $\mathrm{Wu}$ (2018) [9] used theoretical analysis method to analyze the causes of pre-school education major students' professional identity and put forward corresponding Suggestions on this basis. But in general, most of them are theoretical research, less empirical research. The research method mainly adopts questionnaire survey method, theoretical analysis method and interview method, etc. The research content mainly includes the current status of pre-school education normal school students' professional identity, the influencing reasons and corresponding suggestions. Questionnaire survey and interview measurement tools only have simple self-compiled questionnaire survey, and the lack of standardized scientific measurement tools has become a problem that needs to be solved urgently. The purpose of this study is to explore the application of teacher professional identity scale in preschool education normal school students, so as to provide necessary basis for further research in this field.

\section{Methodology}

\subsection{Sample Population}

Sample Population members of the pre-service kindergarten teachers are from topical normal universities in Nanchang, Jiangxi Province. 450 questionnaires were distributed this time, and 405 valid questionnaires were obtained. The effective recovery rate was $90 \%$. Among them have 16 man and 389 women; 82 freshmen, 83 sophomores, 89 juniors and 62 seniors; 221 students from cities and 184 from rural areas. The age ranged from 17 to 25 years and the average age was $20.21(\mathrm{SD}=0.41)$. All samples were randomly divided into two halves, of which 200 (sample 1) were used for exploratory factor analysis, and the remaining 205 (sample 2) were used for confirmatory factor analysis. In addition, 100 people were retested after two weeks.

\subsection{The Instrument Used}

\subsubsection{The Student Teacher Professional Identity Scale for Normal Student}

The professional identity for normal students refers to the comprehensive acceptance and recognition of teachers' occupations and the current status (Wang, Zeng, Zhang \& Li, 2010) [5]. In this study, the student teacher professional identity scale for normal school students developed by Wang et al. (2010) [5] was being used. The inventory is composed of 12 items, which consists of four dimensions: professional value, professional willingness, professional efficiency 
and professional volition with 3 items in each dimension (Wang, Zhu, Liu, \& Chen, 2017) [10]. The 5-point scoring method was used, and subjects were asked to score according to their own actual situation. Due to the special essence of preschool education normal student, the title of the inventory is modified. For example, "teacher" is changed to "kindergarten teacher", "student" is changed to "normal university student". " 1 " means "strongly disagree"; "5" means "strongly agree".

\subsubsection{Study Engagement Inventory}

Study engagement is a lasting, positive emotional and cognitive psychological state of mind related to learning, research and employment. Study engagement holds three dimensions, which is vitality, dedication, and concentration (Fang, Shi, \& Zhang, 2008) [11]. The Chinese version of study engagement revised by Fang et al. (2008) [11] according to the study engagement compiled by Schaufeli (2002) [12], etc. was being used. The inventory consists of 17 items, which can be divided into three dimensions. Likert's 7 points method is being used in this inventory, "0" for "never"; " 6 " for "always". The higher the score, the more study engaged, see Appendix.

\subsubsection{Career Maturity Inventory for College Students}

Liu (2009) [13] defined the degree of career maturity of college students as "the degree to which a college student can make career decisions that are compatible with his or her career development stage and prepare for the corresponding career goals, which include career decision-making knowledge and career decision-making attitudes". The career maturity inventory for college students compiled by Liu (2009) [13] was included. This inventory contains 29 items which consist of 9 dimensions. The 5-point scoring method of A Likter was used.

\section{Findings}

\subsection{Item Analysis}

By analyzing the item-total correlation, we gained the results showed that the correlation coefficient of each item and the total scores of their professional identity were as high as 0.794 and as low as 0.514 . All the items in the scale was significantly correlated with the total score of their professional identity $(p<$ 0.001 ), indicating that they were suitable for further structural exploration, reliability and validity analysis.

\subsection{Exploratory Factor Analysis}

Exploratory factor analysis was conducted for sample 1. The results of Bartlett spherical test and KMO test were significant, with KMO value of 0.799, Bartlett spherical test statistic of $1184.627, P<0.001$. The principal component analysis method was adopted, and the maximum orthogonal rotation of variance (varimax) axis was adopted. Finally, 4 factors were extracted, and the cumulative ex- 
planatory variation of 4 factors after rotation axis was $67.246 \%$. The four factors were named as professional value, professional willingness, professional efficiency and professional volition. Professional values, which mainly focuses on value judgments regarding the teaching profession; professional willingness, which represents the respondents' expectations and preparedness for a teaching career; professional efficiency, which primarily focuses on self-efficacy regarding the teaching profession; and professional volition, which represents the respondent's willingness to continue a teaching career when faced with other career options [10]. See Table 1.

\subsection{Confirmatory Factor Analysis}

To investigate the acceptable of the four-dimensional structure of the pre-service kindergarten teachers' professional identity, we tried the confirmatory factor analysis. The results showed that CMIN/DF index value was 2.777 , less than 5 . The coefficients of NFI, RFI, IFI, TLI and CFI respectively are 0.910, 0.854, $0.941,0.901$ and 0.939 , all greater than 0.8 . The coefficients of PNFI and PCFI respectively were 0.560 and 0.578 , still greater than 0.5 . The coefficient of RMSEA index is 0.047 , less than 0.08 . All the fitting indexes have reached the recommended value, and the model has been well fitted. See Figure 1.

\subsection{Criterion-Related Validity Analysis}

The criterion is the learning investment scale and the vocational maturity scale. The results showed that there was a significant positive correlation among teachers' professional identity, subordinate factors and the scores of the two criterion-related scales, also the correlation coefficients of professional identity, learning investment and vocational maturity were respectively 0.266 and 0.242 $(P<0.001)$. See Table 2.

\subsection{Reliability Analysis}

The whole sample was used to test the internal consistency reliability of the student teacher professional identity scale. The results showed that the internal consistency of teacher's professional identity scale was 0.801 . The reliability of professional value, professional willingness, professional efficiency and professional volition respectively were $0.717,0.628,0.759$ and 0.789 .

100 pre-service kindergarten teachers were selected to investigate the retest reliability after two weeks. The results showed that the retest reliability of the teachers' professional identity scale and subordinate factors were respectively $0.786,0.702,0.616,0.743$ and 0.752 .

\section{Discussion}

This scale consists of 12 short items. According to experts' analysis, each item reflects the professional identity of pre-service kindergarten teachers. During the test, pre-service kindergarten teachers generally respond to questions that are 
Table 1. Exploratory factor analysis of the normal school students' teacher's professional identity scale.

\begin{tabular}{|c|c|c|c|c|c|}
\hline \multirow[b]{2}{*}{ The title number } & \multicolumn{4}{|c|}{ Factor loading after varimax rotated } & \multirow{2}{*}{$\begin{array}{r}\text { Common } \\
\text { degrees }\end{array}$} \\
\hline & $\begin{array}{l}\text { professional } \\
\text { value }\end{array}$ & $\begin{array}{l}\text { professional } \\
\text { willingness }\end{array}$ & $\begin{array}{l}\text { professional } \\
\text { efficiency }\end{array}$ & $\begin{array}{l}\text { professional } \\
\text { volition }\end{array}$ & \\
\hline$t 8$. & 0.840 & & & & 0.731 \\
\hline$t 10$ & 0.828 & & & & 0.760 \\
\hline$t 1$. & 0.720 & & & & 0.644 \\
\hline t6. & & 0.810 & & & 0.701 \\
\hline$t 7$ & & 0.744 & & & 0.663 \\
\hline$t 11$. & & 0.715 & & & 0.560 \\
\hline t3. & & & 0.800 & & 0.776 \\
\hline$t 5$ & & & 0.796 & & 0.783 \\
\hline t9. & & & 0.612 & & 0.553 \\
\hline$t 4$. & & & & 0.766 & 0.698 \\
\hline$t 2$. & & & & 0.764 & 0.612 \\
\hline$t 12$. & & & & 0.664 & 0.588 \\
\hline The eigenvalues & 2.103 & 2.100 & 2.032 & 1.834 & \\
\hline $\begin{array}{l}\text { The variance rate of } \\
\text { contribution }\end{array}$ & 17.528 & 17.502 & 16.931 & 15.284 & \\
\hline $\begin{array}{c}\text { The accumulated } \\
\text { variance rate of } \\
\text { contribution }\end{array}$ & 17.528 & 35.030 & 51.962 & 67.246 & \\
\hline
\end{tabular}

Table 2. The correlation coefficient between pre-service kindergarten teachers' professional identity, their subordinate factors, study engagement and career maturity.

\begin{tabular}{cccccc}
\hline The criterion & $\begin{array}{c}\text { Professional } \\
\text { volition }\end{array}$ & $\begin{array}{c}\text { Professional } \\
\text { efficiency }\end{array}$ & $\begin{array}{c}\text { Professional } \\
\text { value }\end{array}$ & $\begin{array}{c}\text { Professional } \\
\text { willingness }\end{array}$ & $\begin{array}{c}\text { Professional } \\
\text { identity }\end{array}$ \\
\hline Study Engagement & $0.218^{* *}$ & $0.266^{* *}$ & $0.181^{* *}$ & $0.260^{* *}$ & $0.257^{\star *}$ \\
Career Maturity & $0.096^{* *}$ & $0.242^{* *}$ & $0.194^{* *}$ & $0.240^{* *}$ & $0.302^{* *}$ \\
\hline
\end{tabular}

easy to understand and answer. It takes about 5 minutes to fill out the questionnaire, which is easily accepted by pre-service kindergarten teachers.

Exploratory factor analysis found that the student teacher professional identity scale in pre-service kindergarten teachers contained 4 factors (professional value, professional willingness, professional efficiency and professional volition), which were consistent with the original author's structure [5]. The results of confirmatory factor analysis show that the modified scale has certain good structural validity.

In terms of the criterion-related validity, the results show that there is a significant positive correlation among the professional identity scale, the learning investment scale and the vocational maturity scale, which is consistent with the theoretical concept of the scale. The theory manifests that students with high professional identity also have high levels of learning engagement and vocational 


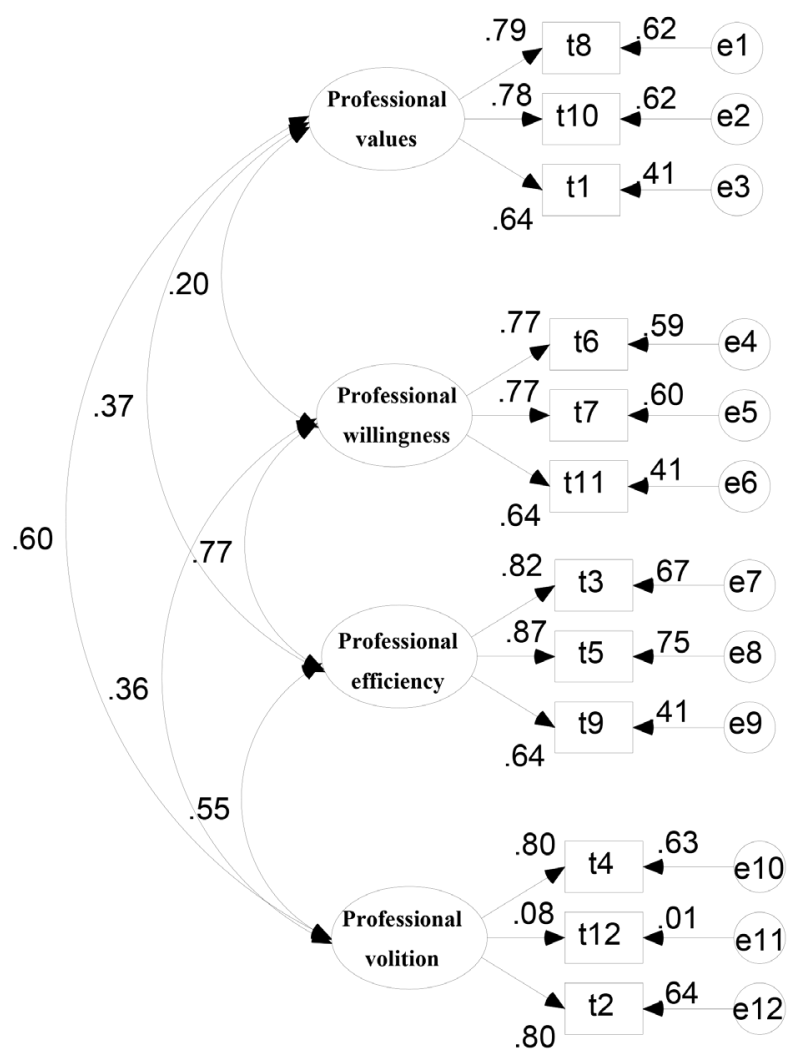

Figure 1. Standardized path figure of four-dimensional structure of pre-service kindergarten teachers' professional identity.

maturity. This indicates that the revised scale has good validity of correlation. In terms of reliability, the internal consistency of teacher's professional identity scale was 0.801 and the four subscales were from 0.628 to 0.789 . Two weeks test-retest reliability was from 0.616 to 0.786 . This suggests that the total scale and component scales have good internal consistency reliability and test-retest reliability.

\section{Conclusion}

From the above analyses, the revised student teacher professional identity scale in pre-service kindergarten teachers has good reliability and validity, which can be used as a standardized and effective tool to evaluate the pre-service kindergarten teachers' professional identity.

\section{Funding}

This work was supported by the Jiangxi Normal University Project of Humanities and Social Sciences "The cultivation mechanism innovation and quality monitoring research of free normal students based on the professional identity perspective", The key project of the 13th five-year plan of education science in jiangxi province in 2018" Research on the influence of work pressure and professional identity on teachers' behavior and countermeasures" (18ZD012). 


\section{Conflicts of Interest}

The authors declare no conflicts of interest regarding the publication of this paper.

\section{References}

[1] Xu, Q.Q. (2015) Analysis on the Development Trend and Existing Problems of Pre-School Education Undergraduate Major Setting-A Sample of 26 Application Forms for Undergraduate Major Setting in General Institutions of Higher Learning. Pre-School Education Research, No. 2, 30-36.

[2] Cheng, W., Wang, Z.Y. and Wang, Y. (2008) A Survey on the Status Quo of Professional Identity of Primary and Secondary School Teachers of Education Major Students of Higher Normal University. Teacher Education Study, 20, 45-48.

[3] Wang, Y.L. (2011) Career Identity of Pre-School Education Undergraduates: Difficulties and Solutions. Journal of Changjiang University (Social Science Edition), 34, 135-137.

[4] Fu, Z.Y. (2004) On the Cultivation of Professional Emotion of Teachers in Normal School Students from Teacher's "Education Love". Hunan Normal University Science Journal of Education, No. 1, 101-104.

[5] Wang, X.Q., Ceng, L.H., Zhang, D.J. and Li, S. (2010) An Initial Research on the Professional Identification Scale for Normal Students. Journal of Southwest University (Social Sciences Edition), 36, 152-157.

[6] Wang, J. and Xue, Y.C. (2011) Investigation and Research on Current Status of Professional Identity of Pre-School Education Undergraduates. Journal of Heilongjiang Institute of Technology (Comprehensive Edition), 11, 3-4.

[7] Zhang, Y.Y., Su, X. and Wang, B.Q. (2015) Study on the Current Situation and Influencing Factors of Pre-School Education Students' Professional Identity. Journal of Chizhou University, 29, 10-12.

[8] Yang, R. and Zhao, Z. (2016). Research on the Professional Identity of Pre-School Education Students-A Case Study of Tongren Infant Normal College. Journal of Chongqing Urban Management Vocational College, 1, 70-73.

[9] Wu, Y.N. (2018) Research on Professional Identity of Pre-School Education Undergraduates. Modern Communication, No. 9, 159-158.

[10] Wang, X.Q., Zhu, J.C., Liu, L. and Chen, X.Y. (2017) Cognitive-Processing Bias in Chinese Student Teachers with Strong and Weak Professional Identity. Frontiers in Psychology, 8, 784. https://doi.org/10.3389/fpsyg.2017.00784

[11] Fang, L.T., Shi, K. and Zhang, F.H. (2008) Research on Reliability and Validity of Utrecht Work Engagement Scale-Student. Chinese Journal of Clinical Psychology, 16, 618-620.

[12] Schaufeli, W.B., Salanova, M., Gonzálezromá, V. and Bakker, A.B. (2002) The Measurement of Engagement and Burnout: A Two Sample Confirmatory Factor Analytic Approach. Journal of Happiness Studies, 33, 71-92. https://doi.org/10.1023/A:1015630930326

[13] Liu, L.M. (2009) Revision and Development Characteristics of Occupational Maturity Questionnaire for Undergraduates. Master's Thesis, Southwestern University, Chongqing. 


\section{Appendix-Chinese and English Versions of the Student Teacher Professional Identity Scale in Pre-Service Kindergarten Teachers (STPIS-PK)}

请根据你的实际情况，对下面的内容做出相应的等级评定：其中，数字 1 表示“完全不同意”，2 表示“比较不同 意”，3 表示“不确定”，4 表示“比较同意”，5表示“完全同意”

According to your actual situation, please make corresponding rating assessment for the following content: " 1 " means "strongly disagree", "2" means "relatively disagree", "3" "means uncertain", "4" means "relatively agree", and "5" means "strongly agree"

\begin{tabular}{|c|c|c|c|c|c|}
\hline items & $\begin{array}{c}\text { 完全不同意 } \\
\text { strongly disagree }\end{array}$ & $\begin{array}{c}\text { 比较不同意 } \\
\text { relatively disagree }\end{array}$ & $\begin{array}{l}\text { 不确定 } \\
\text { uncertain }\end{array}$ & $\begin{array}{l}\text { 比较同意 } \\
\text { relatively agree }\end{array}$ & $\begin{array}{l}\text { 完全同意 } \\
\text { strongly agree }\end{array}$ \\
\hline 1) 我认为学前教育师范生受人尊敬 & & & & & \\
\hline $\begin{array}{l}\text { 1) I think that pre-service kindergarten teachers are res- } \\
\text { pected }\end{array}$ & 1 & 2 & 3 & 4 & 5 \\
\hline $\begin{array}{l}\text { 2) 毕业后若有选择其他职业的机会, 我还是会选择做幼师 } \\
\text { 2) If I could choose another career after graduation, I } \\
\text { would still choose to be a kindergarten teacher }\end{array}$ & 1 & 2 & 3 & 4 & 5 \\
\hline $\begin{array}{l}\text { 3) 我能成为一名合格的幼师 } \\
\text { 3) I think I can become a qualified kindergarten teacher }\end{array}$ & 1 & 2 & 3 & 4 & 5 \\
\hline $\begin{array}{l}\text { 4) 我会在幼师行业干一辈子 } \\
\text { 4) I'll be a kindergarten teacher for life }\end{array}$ & 1 & 2 & 3 & 4 & 5 \\
\hline $\begin{array}{l}\text { 5) 我认为自己能成为一名优秀的幼师 } \\
\text { 5) I think I can become an excellent teacher }\end{array}$ & 1 & 2 & 3 & 4 & 5 \\
\hline $\begin{array}{l}\text { 6)我希望培养幼儿的健康人格 } \\
\text { 6) I hope to aid the development of healthy personalities } \\
\text { in children }\end{array}$ & 1 & 2 & 3 & 4 & 5 \\
\hline $\begin{array}{l}\text { 7) 我有与一线幼师交流的意愿 } \\
\text { 7) I have the willingness to communicate with excellent } \\
\text { kindergarten teachers }\end{array}$ & 1 & 2 & 3 & 4 & 5 \\
\hline $\begin{array}{l}\text { 8) 我认为幼师的社会地位高 } \\
\text { 8) I think that kindergarten teachers' social status is high }\end{array}$ & 1 & 2 & 3 & 4 & 5 \\
\hline $\begin{array}{l}\text { 9) 我能掌握教学技能 } \\
\text { 9) I have the ability to master teaching skills }\end{array}$ & 1 & 2 & 3 & 4 & 5 \\
\hline $\begin{array}{l}\text { 10) 我认为幼师的工作能被他人看重 } \\
\text { 10) I think the work of kindergarten teachers can be } \\
\text { valued by others }\end{array}$ & 1 & 2 & 3 & 4 & 5 \\
\hline $\begin{array}{l}\text { 11) 我有与幼儿交流的意愿 } \\
\text { 11) I am willing to communicate with infant }\end{array}$ & 1 & 2 & 3 & 4 & 5 \\
\hline $\begin{array}{l}\text { 12) 工作若干年后, 我可能转行从事非教育工作 } \\
\text { 12) After working many years, I may engage in other } \\
\text { types of work }\end{array}$ & 1 & 2 & 3 & 4 & 5 \\
\hline
\end{tabular}

